\title{
Peran Brush Border Membrane Vesicle (BBMV) dalam Proses Infeksi Baculovirus
}

\author{
ARMAN WIJONARKO \\ Fakultas Pertanian Universitas Gadjah Mada \\ JL. Sckip Unit 1, Yogyakarta \\ (diterima Maret 2004, disetujui Agustus 2005)
}

\begin{abstract}
The Role of Brush Border Membrane Vesicle (BBMV) in The Baculovirus Infection. Although baculovirus becoming recognized as potential important agents for control pests, there are several important obstacles for commercial use as insecticide. One important obstacle is their narrow host. The other obstacle is due to its developmental resistance, the phenomenon whereby host larvae become progressively more resistant to fatal infection as they age within and among instars. From practical stand point, this phenomenon impacts the effectiveness of baculovirus control programs against agricultural and forest insect pests that is necessary to adjust application levels in the response to the demography of the target insect population. Purified columnar cells derived from midgut of armyworm Psevdaletia separata was used for fusion assay and observed by means of fluorescence assay based on self-quenching of octadecylrhodamine B chloride (R18). Confocal microscopy of the columnar cells that had been combined with labeled virus showed that the fluorescence appeared on the apical part in the brush border membrane, this indicated that there was fusion between virus and the cells. Two dimensional SDS-PAGE and immunobloting assay confirmed that the receptor exist within the columnar cell.
\end{abstract}

KEYWORDS : BBMV, baculovirus, infection.

\section{PENDAHULUAN}

Kebanyakan mikrobia patogen serangga (MPS) seperti bakteri, protozoa, dan virus, masuk ke dalam tubuh inangnya lewat saluran pencernaan. MPS secara pasif bersama-sama dengan makanan melewati usus depan hingga sampai usus tengah serangga. Usus tengah serangga mempunyai berbagai fungsi penting diantaranya pencernaan, penyerapan, pengeluaran air, dan menjaga keseimbangan konsentrasi ion, serta sebagai "barrier" untuk mencegah masuk nya mikrobia patogen ke bagian tubuh yang lain (Boucias and Pendland, 1998).

Lapisan epithelial usus tengah terdiri atas tiga sel utama, yaitu : columnar cells, regenerative cells, dan goblet cells. Columnar cells, yang merupakan bagian terbanyak berfungsi sebagai tempat pembentukan enzim pencernaan sekaligus menyerap makanan. Kondisi kimiawi dan biologis saluran pencernaan di usus tengah ini memainkan peranan sangat penting dalam proses infeksi MPS (Granados and Frederici, 1986). 
Salah satu keperluan dasar berkaitan dengan penggunaan Baculovirus sebagai biopestisida adalah pengetahuan dasar tentang biologi Baculovirus baik secara in vivo maupun in vitro, serta pengetahuan ekologi Baculovirus dalam kaitannya dengan manipulasi lingkungan. Memahami bagaimana suatu MPS termasuk di dalamnya Baculovirus, menginfeksi inang, mulai dari proses inisiasi infeksi hingga perkembangannya di dalam tubuh adalah termasuk bagian dari pengetahuan dasar untuk bisa memahami karakteristik hubungan antara Baculovirus dan inangnya (Barbosa, 1998).

Berawal dari fenomena bahwa inokulasi oral Autograpba californica MNPV pada larva Pseudaletia separata yang ternyata memberikan hasil negatif, sedangkan bila disuntikkan secara intra bemocoelic atau diberi tambahan "Viral Enbancing Factor (VEF)" memberikan hasil yang sebaliknya, maka diasumsikan terdapat "scsuatu" di dalam usus tengah yang menghalangi terjadinya infeksi. Pada kesempatan ini disajikan hasil-hasil pemurnian columnar cell dan uji pendahuluan fusi antara virion Baculovirus dengan coimmar cells tersebut.

\section{BAHAN DAN METODE}

\section{Serangga}

Larva Pseudaletia separata dipelihara dengan pakan buatan menurut Hattori and Atsuzawa (1980). Telur P. separata di sterilisasi dengan $2 \%$ formaldehida dan $70 \%$ etanol, kemudian dipelihara secara aseptis di dalam labu erlenmeyer hingga stadia yang diinginkan untuk keperluan pemurnian BBMV.

\section{Melabeli Virus}

Pseudaletia unipuncta NPV (Psun NPV) diperbanyak dan dimurnikan menurut Wijonarko and Hukuhara (1998). Hasil akhir NPV disimpan dalam lemari pendingin $-20^{\circ} \mathrm{C}$. Virion dari hasil pemurnian PsunNPV diberi label octa decylrbodamine $B$ chloride sesuai dengan diskripsi Hukuhara and Wijonarko (2001) di dalam gelap selama 1 jam dengan menggunakan rotary shaker dan selanjutnya disimpan dalam Hepes buffer.

\section{Pemurnian Columnar Cell}

Columnar cell dimurnikan dengan cara mengambil 5-7 usus tengah larva instar enam, kemudian dibersihkan dari trakea, badan malpigbi, atau jaringan lain yang dianggap tidak perlu. Usus ini kemudian diinkubasikan di dalam $25 \%$ trypsin selama 15 menit pada suhu $37^{\circ} \mathrm{C}$. Setelah dibilas 3 kali dalam PBS buffer, hasil inkubasi disaring dengan menggunakan unit penyaring yang terdiri atas 2 lapis kertas pembersih lensa. Hasil akhirnya kemudian dilihat di mikroskop untuk melihat kemurnian columnar cellnya. Total BBMV dimurnikan menurut cara Hukuhara et al. (2003).

\section{Percobaan Fusi}

Percobaan ini dilakukan dengan cara memasukkan virion PsunNPV ke dalam columnar cell, kemudian diamati dengan menggunakan 2 alat, yaitu : 
1) Confocal mikroskop untuls melihat visualisasi fusi antara columnar cell dan virus; dan 2) Spektrofotometer untuk mengukur tingkat intensitas fusi yang terjadi.

\section{Reseptor untuk VEF}

Percobaan untuk mengetahui adanya reseptor bagi VEF di microvill, dilakukan dengan cara melakukan SDSPAGE 2 dimensi terhadap protein microvilli, kemudian ditransfer ke nitrocellulose membrane (Towbin et al., 1979) selanjutnya diinkubasi dengan anti-VEF rabbit serum selama semalam.

\section{HASIL DAN PEMBAHASAN}

\section{Hasil Visualisasi dengan Mikroskop}

Midgut yang memperoleh perlakuan trypsin akan menjadi sel tunggal kolumnar dengan microvill pada bagian ujungnya (Gambar. 1A). Setelah dikombinasi dengan virion yang juga sudah dilabel dengan pewarna berpendar, terlihat bahwa pada bagian microvilli intensitas berpendarnya cukup kuat (Gambar. 1B) dibandingkan dengan bagian yang lain. Gambar $1 \mathrm{C}$ menunjukkan adanya reseptor VEF pada columnar cell. $\mathrm{Hal}$ ini menunjukkan bahwa terjadi fusi antara virus dengan microtilli pada bagian ujung columnarall.

\section{Kuantifikasi Fusi}

Hasil percobaan dengan spektrofluorometer menunjukkan bahwa fusi yang terjadi sangat dipengaruhi oleh $\mathrm{pH}$ buffer yang digunakan. Pada $\mathrm{pH} \mathrm{7,4} \mathrm{per-}$ sentase fusi rendah, Sedangkan pada $\mathrm{pH}$ mendekari kondisi usus tengah yang sebenarnya ( $\mathrm{pH}$ 10,8) terjadi perbedaan persentase nilai fusi yang cukup tajam (Gambar. 2). Hal ini menunjukkan bahwa fusi antara virus yang berasal dari polybedra dengan microvilli menuntut adanya lingkungan $\mathrm{pH}$ tinggi.

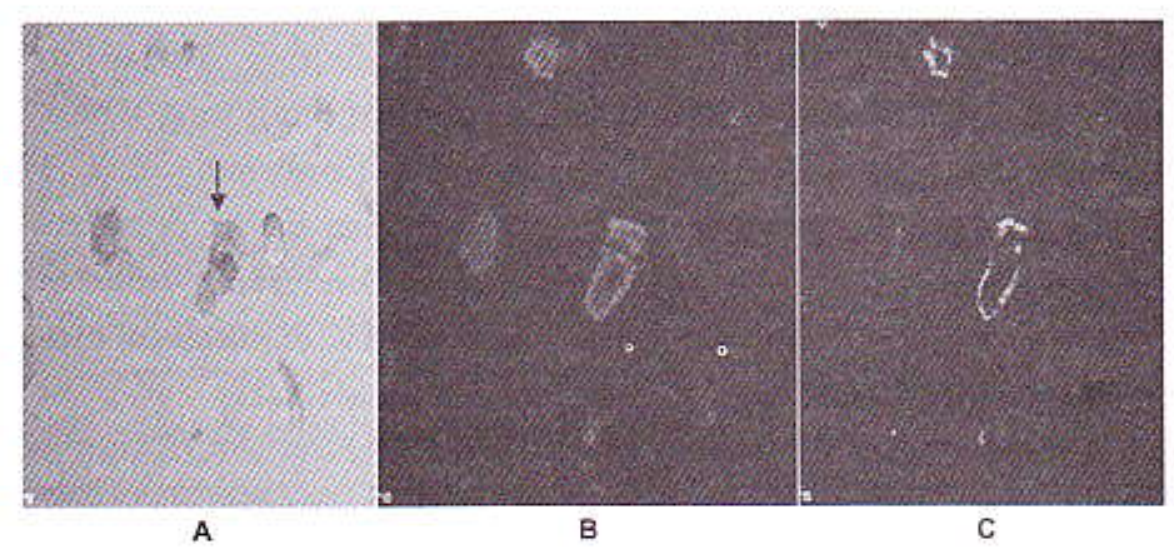

Gambar 1. Microvilli larva $P$. separata hasil permumian dengan trypsinisasi (A) Pengamatan secara Nomarski (B). Hasil pengamatan dengan filter TRTIC, (C) Hasil pengamatan dengan fitter FTIC 


\section{Reseptor}

Hasil SDS-PAGE dan immunoblotting menunjukkan bahwa sangat besar kemungkinan terdapatnya reseptor VEF di microvill, yang diindikasikan dengan band pada membrane hasil bloting (Gambar. 3A dan B). Bolch jadi VEF berperan besar dalam menghilangkan "barrier" dalam usus tengah yang menghalangi proses masuknya virus ke dalam tubuh serangga, dengan cara meningkatkan fusi virus di columnarcell.

\section{KESIMPULAN}

Microvilli larva $P$. separata yang diamati dengan menggunakan filter FTIC menunjukkan adanya fusi antar virus dengan microvilli pada bagian ujung

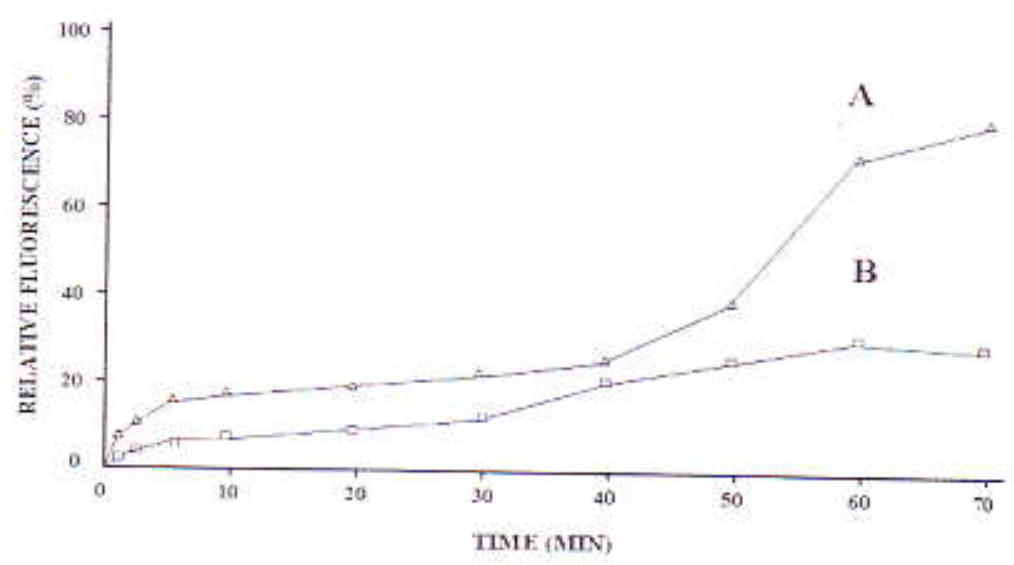

Gambar 2. Fusi kinetik antara Baculovirus dan BBMV larva P. separata (A) pada $\mathrm{pH} 10.8$, dan (B) pada $\mathrm{pH} 7.4$.

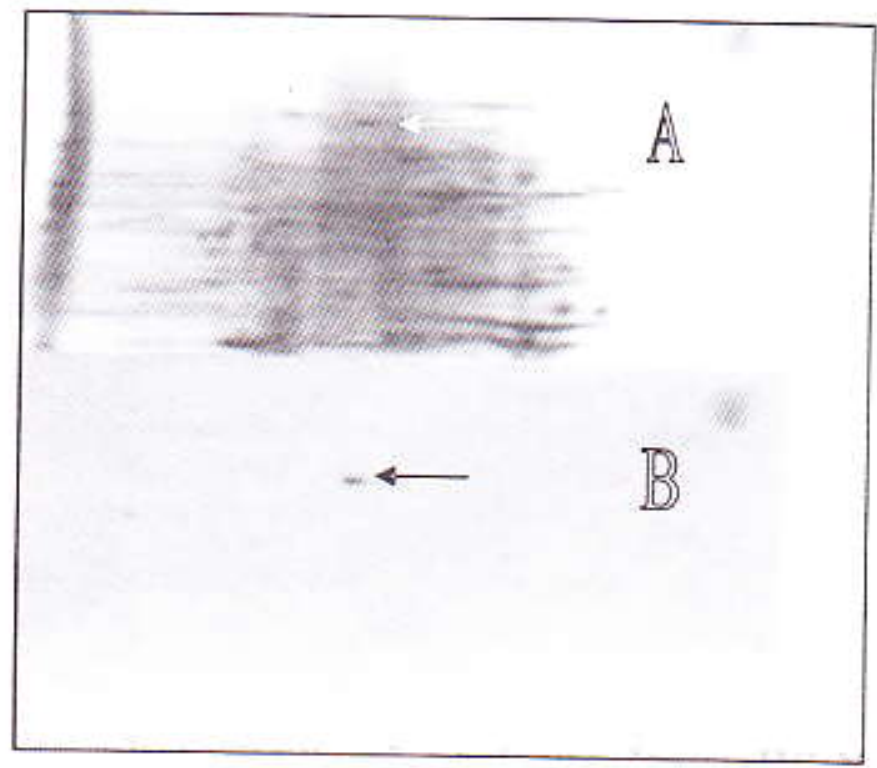

Gambar 3. (A) Electrophoregram protein BBMV hasil SOS-PAGE 2 dimensi.

(B) Visualisasi immunobloting dari protein yang sama 
columnar cell. Terjadinya fusi tersebut dipengaruhi oleh $\mathrm{pH}$ terutama diperlukan $\mathrm{pH}$ yang tinggi. Berdasarkan hasil SDS-PAGE dan Immunoblotting ditemukan adanya reseptor VEF di microvilli yang berperan besar dalam menghilangkan "barrier" dalam usus tengahnya.

\section{DAFTAR PUSTAKA}

Barbosa, P. 1998. Conservation Biological Control. Academic Press. San Dicgo. 396 p.

Boucias, D.G. and J.C. Pendland. 1998. Principles of Insect Pathology. Kluwer Academic. Massachussets. $537 \mathrm{p}$.

Granados, R.R. and B.A. Federici. 1986. The Biology of Baculovirus. Vol II. Practical Application for Insect Control. CRC Press, Florida. $276 \mathrm{p}$.

Hattori M. and S. Atsuzawa. 1980. Mass Rearing of The Cabbage Armyworm, Mamestra brassiase Linn, and Common Armyworm,
Mytbimna separata Wlk. on a Simple Artificial Diet. Jpn. J. Appl EntomoL Zool (in Japanese). (24) $36-38$.

Hukuhara, T. and A. Wijonarko. 2001. Enhanced of a Nucleopolyhedrovirus With Cultured Cells by a Virus Enhancing Factor from an Entomopoxvirus. J. Invertebr. Patbol (77)6267.

Hukuhara, T., A. Wijonarko., H. Iwano, and Y: Hosokawa. 2003. Enhanced infection of an Entomopoxvirus in Larvac of The Armyworm, Psesdaletia separata, by a Granolovirus. J. Appl. Entamol. and Zool. (38) $255-259$.

Towbin, H., T. Stachelin, and J. Gordon. 1979. Electrophoretic Transfer of Protein from Polyacrylamide Gels into Nitrocellulose Sheet, Procedure and Some Applications. Proc. Nath Acad. Sa. US.A. (76) 4350-4354.

Wijonarko, A. and T. Hukuhara. 1998. Detection of a Virus Enhancing Factor in The Spheroid, Spindle, and Virion of an Entomopoxvirus. J. Invertebr. Pathol. (72)8286. 